loaf and biscuits from flour incorporated with food yeast.

During the period covered by the investigations at Teddington it has been possible to supply food yeast to a number of workers who have been interested in determining its nutritive value. Reference has already been made to Macrae's work, which proved its value in pig feeding. Chick ${ }^{8}$ found that food yeast added to white flour ( 73 per cent extraction) increased the value of such flour in rat feeding and made it equal in this respect to wholemeal flour.

Kay at the National Institute for Research in Dairying reports that food yeast is an excellent and palatable high-protein food for pigs and young dairy stock and almost certainly for dairy cows in milk. It produces no intestinal or other disturbances.

In human nutrition, Stephenson, Penton and Korenchevsky 10 record preliminary observations on the value of food yeast when given to aged people with added ascorbic acid. These observers state that in suitable cases improvement in, or disappearance of, some pathological senile features was noticed.

Other workers have tried the value of food yeast in child nutrition; in cases of typical B vitamin deficiencies; in the treatment of jaundice and of certain forms of anæmia. Published reports on these tests are not yet available, but the general conclusion has been that the effect of the addition of food yeast to the patient's diet has been beneficial.

If it may be claimed, therefore, that the microbial protein and the B vitamin concentrate, food yeast, can supplement a restricted diet lacking in animal proteins and their accessory food factors, it is to be expected that the peoples of devastated countries in Europe and the Far East would benefit from its incorporation into their diet. For it is safe to predict that meat and other animal proteins will be in extremely short supply in devastated countries during the immediate post-war period. In fact, there is reason to expect that several years will lapse, after peace conditions have been re-established, before the destroyed herds of cattle of war-ravaged countries can be replaced and the agricultural output of meat and milk be increased to pre-war figures.

The quantities of food yeast which would be needed for incoporation into the restricted diet of Europe after the War could be rapidly provided, and often within the countries themselves, for food yeast production possesses an important advantage over meat production in that it can be completed in hoursr while meat production may take months or years. It would be essential, of course, to have a source of carbohydrate available, but in most devastated countries it should be possible within a single season to set aside a certain amount of carbohydrate for the purpose, either in the form of potatoes or of sugar beet. As for the inorganic nitrogen source required, this should be readily procurable during the post-war period. In this connexion it is worth recording that one acre under a carbohydrate crop could yield $840 \mathrm{lb}$. of protein in the form of food yeast but only some $70 \mathrm{lb}$. in the form of meat or milk protein, while the vitamin $B$ output from the food yeast would be even more than proportionally higher. It is worth mentioning also that, at existing prices, beef or mutton proteins would be five time as dear as food yeast protein, milk protein eight times and egg protein twenty-four times as dear. The $B$ vitamins of beef, mutton or milk would be twenty-five times and of eggs eighty times dearer than those of food yeast.

'Klöcker, “Die Gărungsorganismen”, flrst edition, Max Waag, Stuttgart (1906).

2Mărker, "Handbuch der Spiritusfabrikation", second edition, p. 480 (1877)

${ }^{3}$ Delbrück, Hayduck and Wustenfeld, "Jahrbuch des Vereins der Spiritus Fabrikantem in Deutschland", p. 25 (1910).

" Hayduck, Z. Spiritusindustrie, 38, 161 (1915).

${ }^{5}$ Völtz, Z. Spiritusindustrie, 38, 235 (1915).

'Osborne and Mendel, J. Biol. Chem., 38, 223 (1919).

'Macrea, El-Sadr and Sellers, Biochem J., 36, 460 (1942).

${ }^{8}$ Chick, unpublished data (1941).

- Kay, unpublished report (1940).

${ }^{10}$ Stephenson, Penton and Korenchevsky, Brit. Med.J., ij, 839 (1941).

\section{DEVELOPMENT OF BIOLOGICAL SCIENCE IN RUSSIA}

\section{By $\mathrm{CH}_{\text {H. S. KOSHTOYANTS }}$}

Corresponding Member of the Academy of Sciences of the U.S.S.R

$T$ HE history of the development of the natural sciences in Russia is closely connected with their powerful development in Western Europe and in North America. Indeed, during the initial period of the establishment of the exact sciences in our country, a number of distinguished European scientific men were invited to Russia where, living and working for long periods, they contributed many new pages to world science. Names of members of the Russian Academy of Sciences, such as Karl Ernst von Baer, Pallas, Bernoulli, Euler and others, are well known. Beginning with Michael Lomonosov, many Russian men of science worked and studied in famous laboratories of Great Britain, France and Germany. But it would be wrong to look upon the history of the development of the natural sciences in Russia-as historians of science often do-as only 8 result of the activities of those great men of science from Western Europe who came to Russia and pur. sued their work in the young Russian Academy of Sciences.

Special importance in the history of the development of the exact sciences is attached to the nineteenth century, "the century of natural sciences" as K. A. Timiryazev has repeatedly called it. The main edifice of the natural science of the nineteenth century was constructed in friendly international collaboration by the scientific workers of the Old and New World, and in this work Russian men of science were the originators of a number of important and independent branches of natural science.

The beginnings of an independent science in Russia, emerged in the second quarter of the nineteenth century in an atmosphere of exceptionally intense intellectual activity, and were the result of the great social movement in Russia of the 'fifties and 'sixties which laid the foundation for the emancipation of the peoples of Russia from reaction in oll its manifestations. It came into being as a result of the independent critical advancement of the best achievements of human culture. By the end of the 'fifties, inspired by the philosophical and scientific works of his remarkable compatriots, B. G. Belinsky and A. I. Herzen, N. G. Chernishevsky wrote: "In their conceptions these people no longer depended 
on foreign authorities", and that "Here, for the first time, the intellectual life of our fatherland created men who marched abreast of the thinkers of Europe and not, as had been the case previously, in the ranks of their disciples".

These words, a reflection of "national pride" (Chernishevsky's words), were expressed in the years when there began to appear the first galaxy of Russian men of science, who brought so much glory not only to the Russian people but also to all mankind. The names of Sechenov, Mendeleev, the brothers Kovalevsky, Mechnikov, Pirogov, Butlerov, and, later, Pavlov, Timiryazev and Michurin, speak for themselves.

Long before this period, in the eighteenth century, the work of Michael Lomonosov, son of a Pomor peasant, in physics, chemistry, mathematics and literature entitled him to a place beside the founders of modern exact science-Copernicus, Newton, Lavoisier. As it is now known, Lomonosov, with the vision of a genius, foresaw and created the foundations of a number of new branches of the natural sciences. Unlike his predecessors-the brilliant Western European naturalists and philosophers of the seventeenth century-he not only stood at the peak of knowledge of his own times but also mapped the course of development of the following century. In an address in 1924 on the role of Russian chemistry in world science, Prof. W. P. Wynne, then president of the Chemical Society of London, stressed the fact that even before Lavoisier, Lomonosov had formulated the principles of the chemical theory of combustion and respiration. In fact, the works of Lomonosov have actually provided the impetus for the development of such young branches of natural science as physical chemistry and chemico-physics.

Appearing at the beginning of the nineteenth century, the brilliant mathematical works of Lobachevsky have for many decades and right up to our own days impregnated world mathematical thought. Clifford has vividly described the importance of his work. He declared: "What Vesalius was to Galen, Copernicus to Ptolomeus, Lobachevsky was to Euclid".

By the 'fifties of the nineteenth century the fame of the Russian organic chemists (Zinin, Butlerov and their disciples) had spread across Europe. Their achievements in the synthesis of organic compounds brought into existence a whole line of followers. A number of investigations were carried out by the German chemist, Hofmann, to repeat, confirm and interpret the achievements of the famous Russian organic chemists who worked in the modest laboratory of the University of Kazan, where Lobachevsky was carrying out his scientific exploits. The principles of the artificial synthesis of pigments worked out by Russian chemists re-equipped the technological processes of certain branches of European industry, of German industry in the first place. Certain German chemists have in the past tried to dispute the discovery of the periodic system of elements by the immortal Russian chemist, D. I. Mendeleev. But these attempts were and will be in vain; Mendeleev's work is the basis of modern chemical conceptions.

It is not possible here to discuss the significance of the works of Russian men of science in the development of physics and also of electro-technics. The names of Petrov, Yablochkin, Ladygin, Popov, and finally the brilliant physicist, Lebedev, are associated with the hypotheses and technique of modern physics ; to this important section of the history of Russian thought, specialists must give serious attention.

At the beginning of the 'sixties the famous Russian biologists on whose activities we can dwell here in more detail joined the ranks of the great naturalists of the nineteenth century. First of all, it is necessary to emphasize the role of the Kovalevsky brothers, Alexander and Vladimir. Alexander Kovalevsky showed for the first time that there exist organisms which represent a transitional form between invertebrates and vertebrates. These were the ascidians, which he studied in detail. The German scientific worker, Kupfer, repeated the experiments of Kovalevsky, whose findings and conclusions he confirmed.

At a meeting of the Royal Society of London, a report was given on Kovalevsky's discovery which, as was stated by T. H. Huxley, then president of the Society, created a great impression. Carefully studying Kovalevsky's works, Charles Darwin wrote to Kovalevsky's brother, Vladimir : "Few men will have made such fine discoveries as your brother". It is possible to say without exaggeration that one of the most authentic and convincing proofs of Darwin's evolutionary theory is the group of facts discovered by A. Kovalevsky, one of the world's greatest embryologists, which have been confirmed and recognized by his numerous followers in Europe and America.

In the conversation that took place when K. A. Timiryazev visited Charles Darwin in his house at Downe, in 1877, the latter spoke with particular esteem of the works of the Kovalevsky brothers, especially those of Vladimir. V. Kovalevsky is acknowledged by world science as the founder of evolutionary palæontology. Having explored the vast material on fossil vertebrates, V. Kovalevsky mapped entirely new paths in the field of palæontology and, indeed, laid the foundations of historical palæontology. After visiting a number of European geological and palæontological laboratories, he justly complained of the fact that though many European investigators of his own time were working on important fossil organisms, their work remained a mere description of forms "without any conclusions". This latter impression V. Kovalevsky confided to his brother in a letter referring to German workers in particular. In spite of the fact that V. Kovalevsky actually had no chair and no laboratory and was compelled, because of material difficulties, to do work unconnected with science, the greatest palæontologists of Europe and America are proud to consider themselves his disciples. In his review of the history of palæontology, Henry Fairfield Osborn stated that the works of V. Kovalevsky opened "a new era in palæontology ... [they] swept away all the dry traditional European science of fossils".

With a feeling of deep national pride we must note the fact that among the founders of modern medicine, world science has given to Ilya Mechnikov an honourable place alongside the Frenchman, Pasteur, the Briton, Lister, and the German, Koch. If, with burning conviction, Pasteur and his followers proved that the leading part in the inception and development of diseases in human beings, animals and plants is played by the infection of these organisms with disease-bearing bacteria, to Mechnikov belongs the honour of revealing the main ways in which the struggle goes on between the organisms and the microbes. The Mechnikov theory of phagocytes, so brilliantly argued with much comparative pathological data, actually laid the foundation for modern 
teaching on the process of immunization of organisms to diseases and on the means by which the organisms fight the diseases.

One of the greatest achievements in the field of medicine is the discovery of filtrable viruses. Not very long ago, in 1938, in a résumé devoted to this problem, Anton Dohrn tried to prove that the discovery of filtrable viruses belonged not to the Russian scientist D. O. Ivanovsky but to German investigators. But facts are stubborn things; it was Ivanovsky who, on February 12, 1892, in his report to the Russian Academy of Sciences, for the first time presented data which laid the basis for modern teaching on filtrable viruses. The whole of world science, including the best modern experts on this question, headed by the American, Stanley, who in 1935 discovered the crystalline nature of filtrable viruses, recognizes Ivanovsky as the "father of virus research".

An honourable place among the founders of modern medicine is rightly occupied by N. I. Pirogov, the Russian surgeon, a pioneer of field surgery. A number of classical operations originated by him have not, even at the present time, been excelled in their daring and brilliant simplicity. He methodically worked out the foundations of modern topographical anatomy. Finally, to Pirogov and his disciples belongs the idea and realization of the new method of anæsthesia, the so-called non-inhalational narcosis which, known as the "Russian method", has been widely adopted.

When the young Russian physician, Ivan Sechenov, whose mother was a Kalmuk peasant, first appeared in Western Europe in 1857-58, he soon attracted the attention of noted European scientific workers. Already in his first published work this twentyseven-year-old physiologist discovered and made known the experimental mistake of the celebrated physiologist of the nineteenth century, Claude Bernard. In the very same year the great German physiologist, Helmholtz, wrote that in his laboratory Sechenov had made an important discovery about crystalline fluorization and that in this sphere the work of the Frenchman Renault lagged behind the work of Sechenov in every respect.

Starting work in the laboratory of the brilliant master of physiological experiment, Karl Ludwig, Sechenov realized the inadequacy there of experimental methods for studying the gases of the blood, and he embarked on independent work in this dificult field. Sechenov constructed a special apparatus for the study of gases of the blood which he called the "absorbtometer". Ludwig ordered Sechenov's apparatus for his own laboratory. Experimenters like Helmholtz, Pflüger, Bohr, and, later, Warburg and Barcroft, introduced a number of modifications to the basic model created by Sechenov. Widely used in all modern physiological and biochemical laboratories of the world, appliances for studying gases of the blood and also respiration of the tissues are, despite many small modifications, only variations of Sechenov's model.

In his discoveries of the phenomena of central torpor in the highest sections of the nervous system of animals and man, Sechenov's work has received world recognition. Up to now physiologists of all countries have continued to work on the interpretation of the phenomena discovered by Sechenov. Long before many of the greatest physiologists of modern times, especially the famous British physiologist, Sherrington, and the German physiologist, Hofmann, Sechenov discovered and described in great detail the complicated phenomenon known as muscular sensation. He noted for the first time that the muscular system of animals and man is at the same time the system of the organs of sensation, which fact had great importance in the co-ordination of movements of these organisms. The most complicated physiological laws which underlie the latest conclusions on the mechanism of the co-ordination of movements (particularly the question of so-called antagonistic excitation of the muscles) were originally described in Sechenov's works. First to direct attention to all these facts was Prof. A. F. Samoilov, famous for his work on the physiology of the nervous system.

It is difficult to over-estimate, and even still more difficult to deny, the all-important part played by Sechenov in the discovery of a completely new approach in the physiology of the nervous system, which made possible the objective study of such complicated phenomena as the conduct of animals and human consciousness. This indisputably Russian trend in world physiology was brilliantly developed by Sechenov's closest follower-the scientific genius, I. P. Pavlov.

Among the direct disciples of M. Sechenov we must note the name of one of the greatest Russian physiologists, N. E. Vedensky, who developed Sechenov's work and discovered a number of new laws relating to the most complex questions of the activity of the nervous system. It is possible to say without exaggeration that contemporary physiology of the nervous system is nourished to a great extent by ideas and experimental data belonging to Vedensky or connected with his name. It is well known how much attention British and American schools of physiology have devoted to the elaboration of Vedensky's scientific heritage on the most delicate processes of excitation and torpor of nerve cells and nerve fibres. At the International Congress of Physiologists in 1935, Prof. Louis Lapic, of the Sorbonne, admitted that his own teachings on chronaxie were without any doubt formulated in other terms by Vedensky long before him.

It is unnecessary to speak of the fame of Pavlov and his school. He has been well appraised by the American physiologist Prof. W. B. Cannon: "if they do not know about him they think according to Pavlov's ideas, and if they do not think according to his ideas, their digestion works along those lines".

At the end of the nineteenth century, when Pavlov's book "Lectures on the Work of the Digestive Glands" appeared, the celebrated German physiologist, Funk, observed: "it is dificult to find a scientist who in so short a time has been able to make so many discoveries". Meeting in the U.S.S.R. in 1935, the International Congress of Physiologists unanimously recognized Pavlov as "leader of the physiologists of the whole world". The works of Sechenov, Pavlov, Vedensky and their disciples have won a prominent position for the Russian school of physiology.

The end of the nineteenth century was marked by discoveries by Russian scientific workers which illuminated the most important processes of organic matter-the processes of the synthesis and decomposition of organic matter, and the changes of matter in Nature. On the basis of brilliant and careful experiments, K. A. Timiryazev established new conceptions of the role of chlorophyll and the energy of light in the synthesis of organic matter from carbon dioxide and water. The work of S. Vinogradsky led to the understanding of another most important branch of the synthesis of organic matter in Nature, namely, 
the 'fixation' of nitrogen of the air by the synthesis of complex organic nitrogen compounds. Vinogradsky's discovery of the relation of atmospheric nitrogen to soil bacteria represents a new epoch in biology and agriculture.

From different aspects, the work of V. Paladin and A. Bach led to an understanding of the biochemical processes forming the basis of the respiration of plants and animal cells.

From its inception the evolutionary teaching of Charles Darwin had ardent protagonists in Russia among philosophers and scientific men such as Pisaryev, Timiryazev, Mechnikov, and, later, Mensbir and A. N. Severtsov. At the very beginning of the twentieth century, simultaneously with Sedgwick, A. N. Severtsov widened and deepened Darwin's teachings by his work on the study of the relationship between the individual and the evolutionary development of organisms.

All these achievements of Russian biologists during the nineteenth century form the basis for the manysided development of science in Russia which has characterized recent years. Scientific men of the U.S.S.R., fully aware of their debt to their people, always remember the words of one of their teachers, I. P. Pavlov, who said: "Our fatherland opens vast fields to scientists, and it is necessary to repay the debt; science is generously introduced into the life of our country - to the last degree, generously . . . and for us it is a matter of honour-to fulfil the great hopes that our country places on science".

\section{ASPECTS OF INDIAN INDUSTRIAL DEVELOPMENT}

$\mathrm{P}$ RIOR to the War of 1914-18, Indian industrial development, except for the textile industries based on cotton and jute, were on a minor scale. The great Tata iron and steel works at Jamshedpur were still in process of erection and it was not until after 1917 that it was in a position to make a major contribution to the war effort. Public opinion had already forced the Government of India to recognize the desirability for a more rapid industrial development, resulting in the appointment of the Indian Industrial Commission. Unfortunately, many of the recommendations made in the Commission's valuable report were not implemented, nor was much attention paid to the suggestions for the development of chemical and metallurgical industries made in the pamphlets issued by the Indian Munitions Board. The temporary impetus resulting from the War soon died down and almost the only large-scale industry based on science which developed during the next two decades was that of soap and related products, manufactured by modern methods, in the Tata Oil Mills. It would serve little purpose, nor would it indeed be profitable, to discuss the varied causes for this, but one of the main causes has undoubtedly been lack of adequate technical advice and of skilled labour.

Now, with another war of world-wide range, the opportunity has once more arrived for India to become industrialized, and this time we feel there can be no relapse. As a supply centre for the Near and Far East she occupies a key position. This time it is possible for the advance to be planned and to be based upon solid scientific research. It is true that for many years now, cotton, jute and lac have had their research organizations, and therein lies probably the cause of their prosperity, but planned industrial research on the many problems of the chemical and metallurgical industries under tropical conditions has been almost completely lacking. This gap has now been filled by the new Board of Scientific and Industrial Research. A further guarantee that the fundamental chemical industries will be established on an adequate scale is furnished by the decision of Imperial Chemical Industries, Ltd., to form an Indian company. We may anticipate that this will meet with success equal to that achieved by the similar organizations in South Africa and Australia.

Rich as India is both in mineral and plant products, she is, like other countries, by no means fully selfsufficient. The main coal deposits are situated far from the Punjab, Bombay and Madras, although this lack of fuel is to some extent compensated by cheap electricity generated by water-power. A further fundamental requirement is sulphur for the manufacture of sulphuric acid, since even now it is true that the consumption of sulphuric acid provides an index of a country's industrial development. India drew her supplies of sulphur almost entirely from enemy countries, Italy and Japan, and although the immediate war-time needs are being met from the comparatively small deposits in Baluchistan, these, besides being difficult of access, would be quite inadequate in normal times. A nearby and practically inexhaustible source of supply could be made available by the desulphurization of the waste gases from the Anglo-Iranian oil-fields. In an interesting paper, Forrester and Gilbert (Trans. Min., Geol. and Metal. Inst. India, 37, 61-168; 1941) have surveyed some aspects of chemical and metallurgical industries as applied to Indian conditions, and they suggest that considerable quantities of sulphur dioxide could be recovered from the Indian Copper Corporation's smelting plant. This source, were it developed, would, however, only very partially meet India's normal requirements, and other sources will have to be found. The former possibility would appear to be worthy of careful consideration, since it would at the same time give a gas suitable for the manufacture of a highclass carbon black.

Whereas the metallurgical industries based on iron are already developed on a large scale in India, no attempt has been made so far to establish the manufacture of either aluminium or magnesium, although much has been written on the subject. For the manufacture of the former, both the necessary raw materials and cheap electrical power are available, so that presumably lack of capital and of adequate scientific assistance have caused the delay in the establishment of this essential industry. The growing importance of the lighter alloys would justify also the manufacture of magnesium, for which the separation of magnesium salts from sea water by modern methods would provide the necessary material.

In their paper, referred to above, Forrester and Gilbert tabulate a long list of coal-tar products which are now being made in India; but with the relatively small and scattered gas plants which are in operation, it would appear doubtful if a large-scale industryand to be economically successful it must be on a large scale-can be developed from coal-tar. It would seem that in India a synthetic chemical industry 